\title{
Dialogues in the Making: Collaborative Archaeology in Sudan
}

\author{
Claudia Näser \& Gemma Tully
}

\begin{abstract}
In this paper we introduce the Mograt Island Collaborative Project. Launched in 2014, this project aims to share archaeological narratives with members of a local community in Sudan, and with other stakeholders engaged with the area's past, building on a collaborative process which investigates how archaeological outputs can be explored together in a meaningful way. We discuss the wider context in which the project takes place, its individual steps, the factual outcome of its first phase, and its evaluation in spring 2018. We share this case study to promote collaborative practice in postcolonial, present-day majority Muslim contexts, such as the Nile valley countries, where the approach is thus far underrepresented. Reflecting on the project's trajectory and its results, we also present critical thoughts on its potentials and challenges which can be helpful for readers working in similar contexts.
\end{abstract}

\section{Keywords}

collaborative archaeology, co-production, community publication, Mograt, Sudan, Nile valley

\section{Introduction}

Collaborative, community or public, archaeology has developed into an established field of global archaeology in the last 50 years. Although open to criticism on the 'truthfulness' of their methods (e.g. Pyburn 2007; La Salle 2010), outreach and collaboration with present-day publics have become integral parts of archaeological practice in many regions with assertive descendant communities, namely, North America and Australia (e.g. Smith and Wobst 2005; Atalay 2006; Murray 2011). In other regions of the world, similar approaches established more slowly. This was due, in part, to less intense political and social pressure in contexts without histories of colonial rule. But the situation is also true for a number of postcolonial nations and peoples in regions where 'prized histories' (and their physical remains) have been disconnected from living communities through the rhetoric and practices of (ex-)colonial powers. Among these areas are majority Muslim countries in Southwest Asia and North Africa. In Egypt, for example, the first community archaeology projects only started in the late 1990s. Interestingly, all 'early' projects took place outside the Nile valley, namely in Quseir (Moser et al. 2002; Tully 2009) and Berenike (Bos-Seldenthuis 2007; Wendrich 2008; Abdel-Qadr 2013) at the Red Sea coast, and in Serabit al-Khadim on Sinai (Hanna, Keshk, and Aboubakr 2013). Only in the past decade has community engagement reached the Nile valley proper, the classic domain of Egyptian archaeology (Fushiya 2010; Tully and Hanna 2013; Lorenzon and Zermani 2016; Regulski 2018). But with less than $5 \%$ of the current archaeological projects in Egypt incorporating a community component, such engagements remain the exception, rather than the rule. ${ }^{1}$ In the Middle Nile valley, i.e. Sudan, the 'collaborative turn' has just begun, with the first fully-fledged community projects emerging only in the past five years (see below, but for earlier related approaches see Haberlah 2007; Näser 2007). 
The reasons why collaborative archaeology has been so slow to take root in these contexts, why it now gains momentum, and what we can learn from these constellations still requires detailed reflection. Doubtlessly, the combination of a deep history of colonial rule and a present-day majority Muslim population, alongside the specific profiles of archaeological research in these regions, with their impacts on individual and collective perceptions and self-perceptions of contemporary stakeholders have contributed to this delay (Näser forthcoming). This paper is not aiming at exploring these background factors on a general detached level, though we comment upon them in our conclusion. Our primary aim is to present a case study from Sudan as a contribution to the discussion and promotion of collaborative approaches to archaeology in this region, and in politically and socially similar contexts, where such approaches are still heavily underrepresented.

\section{The Mograt Collaborative Project: Context and considerations}

The main triggers for the wave of collaborative archaeology to reach Sudan were decidedly political and financial. The Qatar Sudan Archaeological Project, which started in 2013, endowed 42 archaeological missions ${ }^{2}$ from 25 institutions in twelve countries with substantial five-year funding (http://www.qsap.org.qa/en/qsap-sites.html). It was connected to the express request for site management and public outreach (http://www.qsap.org.qa), but it did not call for community engagement, thus the introduction of collaborative approaches was dependent on the personal commitment of individual archaeologists. Even so, several missions embarked on collaborative heritage and community archaeology projects (Tully 2014, 2015; Fushiya 2017; Humphris and Bradshaw 2017). Some of them have started to make an impact, primarily by generating resources in Arabic (Tully and Näser 2016; Fushiya et al. 2017; Ryan 2018) and Nubian ${ }^{3}$, but most have yet to complete the 'full cycle' i.e. following the dissemination of their factual outcomes with an evaluation and a reflection on project results. The Mograt Collaborative Project has reached this stage - this paper is part of the evaluation of the project's first phase and its results.

The Mograt Collaborative Project started in 2013 as part of the Mograt Island Archaeological Mission (MIAMi). Mograt is the largest island in the Nile (fig. 1) and has a multi-layered history from the Palaeolithic to the modern day (https://www.mogratarchaeology.com). Archaeologists have visited Mograt over decades, but undertook only limited survey work and no excavations before 2006 (Ahmed 1971). None of the earlier enterprises considered the impact of their presence on local communities or sought to consult with them. This is also true for three seasons of fieldwork which Claudia Näser conducted with a predecessor project between 2006 and 2008 (for reports see https://www.mogratarchaeology.com/publications/by-fieldseason), as well as a survey undertaken by the National Corporation for Antiquities and Museums in 2011 (unpublished).

The initial aims of the Mograt Collaborative Project were to explore the interests of the island's residents and other stakeholders in the archaeologically approachable past and, if they wished, to collaboratively develop resources for this community and other Sudanese publics to engage with this past. While this sounds straightforward, our approach acknowledges that we move on contested ground. The role which archaeology and its practitioners played in the colonial domination of Nile valley societies has seen substantial research (e.g. Trigger 1984, 1994; Scham 2003; Colla 2007). How western archaeologists have asserted their role in the power reconfigurations of the postcolonial era has received much less attention (but see Carruthers 2016; Näser forthcoming). We acknowledge that the legacies of Sudan's colonial past, as well as its difficult postcolonial present, permeate our practices and our interactions with all stakeholders. These legacies surface primarily, but not exclusively, in the stark economic asymmetries and the widely 
differing access to resources in multiple social and cultural domains which local community members command in comparison to us. Adopting a concept from critical race theory (McDavid 2007, 68), this condition could be captured under the term 'colonial privilege', which we propose to define as the continued, though largely unacknowledged existence of advantages connected to individuals from Western contexts, and the entitlements that they demand on that basis. Colonial privilege cannot be transcended by any well-meaning action as it is rooted in deeper socio-political and economic structures (La Salle 2010; Näser forthcoming). It inhabits all our interactions, and by our very presence in the study areas, we constantly reproduce it. However, we have taken guidance from Carol McDavid $(2007,69)$ who has argued that 'we must not be immobilized by fears that we are not' - and we would argue: cannot possibly be - ethically 'correct enough'. McDavid suggests that we should be pragmatic and let time be the judge whether our actions and strategies were appropriate. This also means that our practices and their outcomes must not be seen as solutions, but as statements inviting further engagement.

Following from this, it was essential that we try to communicate with community members in ways which could reduce the inherent power imbalances while still acknowledging their existence. One crucial strategy was to explicitly avoid collecting data related to the community and their knowledge of archaeological sites and artefacts. By shifting the threshold for engaging with us, we could make it clear that we did not seek any kind of 'information exchange'. We wanted to prevent a scenario where we would benefit without adding anything of value to those engaging with us.

The notion that archaeologists extract and then remove resources is pervasive among residents accustomed to non-inclusive archaeological projects in Sudan and beyond (e.g. Humphris and Bradshaw 2017, 211; Mehari and Ryano 2016, 34-36). These stakeholders have witnessed the fact that none of the recovered objects or data make their way into their communities (see Näser and Kleinitz 2012). To counter this perceived, and real, drain of resources, we focussed on building relationships around introducing us and our work, offering to share what we do, and explore with community members whether (and if so: how) it might be meaningful to them. The only data we collected were about the collaboration itself, as well as largely anonymized basic personal information which enabled us to link responses to specific demographics. The latter was necessary to generate adequate resources for different groups within the community and for other stakeholders, and to re-identify them in the dissemination and feedback process ${ }^{4}$.

\section{The Project Trajectory}

\section{First Field Season: Getting Started}

The focus of the first field season in spring 2014 was to introduce us and the project to community members living close to MIAMi's main excavation site, the multi-period cemetery MOG034 in alKarmal (see fig. 1). We wanted to develop transparency around our presence in general, and the members of the collaborative team in particular, and to create settings in which we could work together, find questions important to all of us, and generate meaning by constructing group knowledge (Tully 2014). To achieve this, we adapted a methodology built on approaches drawn from archaeological ethnography (also known as ethnographic or ethnocritical archaeology; Castañeda and Matthews 2008; Zimmerman 2008; Hamilakis 2011) and collaborative archaeology (also known as community archaeology; Thomas 2017; Tully and Allen 2018). We derived insights from previous projects in Egypt (Tully 2009; Tully and Hanna 2013) and a contested salvage operation in the area of the Fourth Cataract, just downriver from Mograt (Näser and Kleinitz 2012). Our approach built on formal and informal interviews, site and home visits as well as visits to schools and other community 
fora by members of the collaborative team (Gemma Tully, Hassan Mustafa Alkhidir) and other team members, with the aim of starting dialogues and building mutual understanding. By maintaining a position of openness and involvement from the start, we quickly became part of wider conversations regarding the intermingling of daily life and Mograt's present and past with a range of people. Comparisons began between the archaeological work and local use and knowledge of cemetery MOG034, as well as other archaeological sites on the island. These allowed us to consider with equal weight the input of community members alongside archaeological findings. It was the first step towards helping all parties to appreciate plural ways of seeing and generated active discussion and debate.

A series of key questions emerged that we answered on a one-to-one basis where possible, but also identified as inviting further exploration through publications, community events, and online material. We divided the questions between issues relating to archaeological work and more specific queries concerning the history of their island and its connections with the wider history of Sudan. The first set of questions included:

- What is archaeology?

- What do archaeologists do and why?

- What techniques and tools do archaeologists use and how do different instruments work (largely based on ad hoc visits from community members to the field on seeing equipment such as the total station)?

- What are archaeologists looking for?

- What happens to the things they find?

- How are different types of sites excavated; e.g. is the method used to excavate a graveyard different to that used for a fortress? ${ }^{5}$

- What do archaeologists do with the new knowledge, and how do other people learn what archaeologists have found out?

When we looked for comparative data from other contexts, we found that research frequently asks about what publics know about archaeology, but that surveys about what audiences would like to know are strangely lacking (cf. Tully and Allen 2018, 4). While our data set can only start to fill this gap (cf. Moshenska 2017, 12-13), we suggest that the questions of the people from Mograt are no different to those posed by other non-professionals, from both Global North and developing world contexts (further on this, Näser forthcoming). They reflect, however, an issue that residents frequently reiterated, namely the fact that no previous team had ever taken the time to discuss them. This omission has led to the notion that archaeologists dig for gold and take away everything they find as booty for museums or personal gain (Tully 2015, 202; Humphris and Bradshaw 2017, 211). Repercussions of this include site looting once archaeologists leave, feelings of injustice, and a sense of loss when information is not even 'deposited' to compensate for items which have been removed. We need to add here that 'gold' is not a wrong perception of what people expect to find at archaeological sites. Rather, it is a reasonable way of making sense of the investments archaeologists undertake, using a category denoting utmost value in a country which currently experiences a veritable gold rush on industrial and individual subsistence level (Chevrillon-Guibert 2018).

While transparency alone may not resolve these deep-seated issues, it is a first, critical step in this direction. In our case, conversations with team members led numerous community members to visit excavation sites, talk to archaeologists, and observe, and sometimes try, archaeological work. This aided the collaborative process as both archaeologists and community members developed dialogue and built understanding in each other's 'domain'. Opening up the boundaries of 
archaeological versus community 'space' can help to reduce the cemented feelings of alienation for all parties and is a first step towards sharing these spaces and related practices (Tully 2014, 158).

The second set of questions reflected the interest of community members in the archaeologically approachable history of Mograt, their trust in the ability of archaeology to answer these questions, and the general lack of resources available to local people to explore these issues. Our work has shown that existing historical knowledge primarily relates to family and tribal history and is almost exclusively passed on and shared through oral traditions. Questions included:

- What is so special about Mograt's history; i.e. why do archaeologists come here?

- Is it true Mograt was once two islands?

- How many sites are on the island?

- What dates are the sites from?

- What things have been found at the different sites?

- How does the history of Mograt link to the ancient people of Meroe?

- How many people are buried in the different types of tombs on the island?

- Will important new finds go on display in Khartoum (like others have before)?

- What can be done to stop people using land that was/is an ancient cemetery for farming?

The people who engaged with us expressed strong consensus to know more about our narrative of the island's past and its position in the wider history of Sudan, the Nile valley and the world. This underlined the need not only to discuss findings and answer questions in person and at events, but also to generate lasting, material resources targeted at larger audiences. As a consequence, we wrote a first draft of a bilingual Arabic and English publication 'Discovering Mograt Island Together - هيا بنا نستكشق معاً جزيرة مقرات 'which was to answer many of the questions collected during the field season and to promote the contemporary cultural narratives that were shared. We identified school-age children from 9 to 16 years as the central target audience because the field season had revealed how curious this demographic was to know more about the archaeological team and our work on Mograt. School-aged children also make up about one quarter of the population of the island (approximately 2,500 out of 10,000 people), and almost every family has at least one child in school. As children are keen to share their learning and experiences with their families, working with children would thus mean that this knowledge will spread to community members of all generations. The draft produced during this first stage focused on presenting the work and aims of MIAMi, but also discussed the history of Mograt and wider Sudan as well as archaeological methods on a more general level. It was richly illustrated, with many images directly relating to archaeological sites and finds from the island.

\section{Second Field Season: In-Depth Work}

In the second field season in spring 2015, we took the book draft to Mograt to finalise it for publication. Given its target audience, we set out to consult school children and teachers, but also other community members, about the relevance and suitability of both content and presentation. Gemma and Hassan conducted focus group interviews with over 100 children at one secondary and two primary schools (Tully 2015). In these, several themes and suggestions for additions and adjustments emerged. They included:

- Add an English and Arabic vocabulary page so that archaeologists and community members can learn the most important words in both languages. Example words include archaeology, excavation, pottery, skeleton, and heritage. 
- Add quotations from school children on what the island means to them and link the quotations with subjects discussed in the book.

- Add a map of Mograt in Arabic and English as many people, especially children, do not get the opportunity to explore much of the island and do not have visual resources to help them understand its layout and features.

- Add more detailed information about the techniques and reasons behind the different forms of archaeology (e.g. environmental archaeology, osteology).

- Explain what happens to the objects and the human remains ${ }^{6}$ we find; what do we use them for, where do they go, who studies them, where do they end up after our work has finished?

- Clarify our motivation for doing archaeological work on Mograt; i.e. explain the desire to enhance our knowledge of the history of Sudan alongside other motivations.

- Facilitate local stakeholders in making connections with the past by showing continuity and change on Mograt.

- Add more detail to photo captions, e.g. if a photograph shows a piece of pottery from Mograt, say exactly where on the island it came from.

- Explain what happens to the information we collect. Will the world know about Mograt?

- Explain whether there is archaeology in other places in the world (e.g. in Europe) and help people understand why we come to Mograt if we have archaeology in our own countries.

- Explain what people should do if they find old things/places on the island, or if they have items from their family history, or that have been found in the past, that they would like to know more about.

With this feedback and new data from the field season, we rewrote 'Discovering Mograt Island Together - هيا بنا نستكشق معاً جزيرة مقرات'. We added a timeline, detailing the history of Mograt and Sudan from the present to the Stone Age (fig. 2), an A3 fold-out map, word swap boxes, and quotations and photographs of the children who had participated in developing the book (fig. 3). Following the express request from children and teachers, we also added exact locations to image captions, e.g. which site is shown in the illustration of excavating burials (fig. 3), to enhance their local context. When the book was completed and printed in 2016 we were eager to take it back to Mograt.

However, due to an interruption in funding and a change in the institutional affiliation of the project, our return to the island was delayed until early 2018. The delay inevitably had an impact on bonds of trust with people of all ages who expressed frustration and disappointment towards the team. However, as soon as we shared the book, enthusiasm for it quickly repaired relationships and led to discussions of future projects. The potential for problems and delays, such as we experienced, is something we learned to prepare for, both in terms of the timescale of funding applications and communications with all project partners.

\section{Third Field Season: Disseminating Results and Evaluating Feedback}

The first aim of the spring 2018 season was to disseminate the book to all 14 schools on Mograt (12 primary schools with c. 2000 pupils and two secondary schools with c. 500 pupils; see fig. 1) and to gather feedback. A second aim was to discuss what other resources should be developed to meet the interests of community members and facilitate further knowledge exchange between communities, the archaeological team and other stakeholders. 
Gemma Tully, supported by Rehab Ismail Alfaki and Gareth Rees, held feedback sessions with pupils from eight classes in two primary and two secondary schools (137 primary pupils, 366 secondary pupils) as well as teachers from all 14 schools ( 57 women, 25 men). The primary schools were the same ones where we carried out the book development in the second field season. 35 of the children we worked with were the still there, and we met many others in the secondary schools. We also distributed copies of the book to families and village leaders across Mograt, as well as to politicians and administrators of the Abu Hamed municipality. In these contexts, we held informal feedback sessions with 37 women and girls and 45 men and boys. Finally, we organized a community event at a primary school in Maqall (see fig. 1), the main settlement and location of the market and ferry landing.

In general, the stakeholders we consulted, from children to elders, were overwhelmed by the existence of a book solely about Mograt. At times, the sense of disbelief, mixed with enthusiasm, made it difficult for individuals to articulate their thoughts beyond comments such as 'beautiful', 'wonderful', 'strong'. Thus, it will be essential to re-evaluate the impact of the book at a later point in time, preferably by an external researcher. This will overcome its novelty value and produce data on the longer-term effects of the project (Giblin 2017). The following paragraphs explore some of the comments regarding the publication and the potential for further co-produced resources.

\section{Pupils}

For most pupils, participation in the project was the first time they had heard of archaeology or realised that archaeologists from other countries were working on their island. This was a source of pride and made many want to get out and see the sites.

Learning that so many people have been working here for so long, looking at our old things, makes me happy.

(Quoted from a Class 3 student at Salah al-Din Karrar Girls' Secondary School)

The majority of the children had never visited any of the archaeological sites discussed in the book. Some were aware of sites near to where they lived, but most of those had not realised they were old or potentially important. Qasr Kindi, the fortified seat of a local family of power dating back to the colonial period, the skeletons in multi-period cemetery MOG034, and the Medieval forts (see fig. 1) proved to be of the most interest. Kindi provoked curiosity as the children felt it to be prestigious in terms of recent history. The skeletons were a topic of fascination with techniques of aging and sexing, and because most pupils had never seen human bones before. The forts were popular as standing remains with a clear purpose, and most children had seen at least one of them (even if they had not known what they were). Almost every class asked questions about Kindi, the skeletons and the forts, the majority commenting that they would like to visit them.

When discussing what they learnt in history classes, many children stated that they had not realised there were sites on the island from the same periods they had heard about before reading the book. They integrated book content with previous knowledge, as they learnt about new peoples, periods and cultures. The presence of artefacts from the Stone Age on Mograt particularly impressed many pupils, and many mentioned that they had learnt new concepts and words (in English and Arabic). Some of the most frequently cited were laboratory, biology, fort, heritage, cemetery, 
excavation. When we asked the students who had contributed to the development of the book how the finished version compared to their memories, they were all very impressed. One pupil said,

The book is even better than we imagined. We love that we can see our photos and words printed there.

(Quoted from a Class 1 student at Attar al-Maula Boys' Secondary School)

The most important feedback was how the book had helped pupils to think and see their island in news ways, raising awareness, inspiring pride, and creating a desire for further information and collaboration regarding Mograt's (hi)story. This is best illustrated through a letter written by a pupil from Class 2 at Salah al-Din Karrar Girls' Secondary School (fig. 4).

For one girl who had just moved to the island from Khartoum, the 'pride' element was particularly important:

I had never heard of Mograt before moving here, and I am so happy to have this book and to be able to take it back to Khartoum and tell people about my new place.

(Quoted from a Class 1 student at Salah al-Din Karrar Girls' Secondary School)

Students often linked their comments regarding Mograt's fame and future to remarks about keeping 'special places clean and beautiful', and 'not taking things' or 'robbing graves'. Although we cannot necessarily expect this to have a lasting impact, it might, over time, improve site protection.

Finally, one particularly interesting aspect of the feedback related to the idea of having a museum. One pupil stated:

It is good for our future to have all this new information about our island as in the future we want everything to be better on Mograt and for people to visit from all over the world, both from Sudan and outside. [...] We also want to preserve all our finds in a museum on Mograt.

(Quoted from a Class 7 student at Kalasaikal Gubli Mixed Primary School)

Even though we did ask questions about the potential of a museum at the end of each feedback session, a number of children across the different schools raised the topic independently before this point. This was surprising considering that most of the children had never visited a museum and it is only mentioned once in the book: The section 'What happens to the things archaeologists find?' notes that 'only a few objects will end up in museums; most go into storage' (Tully and Näser 2016, 11). Feedback focused on how a museum might help to preserve and promote Mograt's history:

Building a museum would help to protect the sites and allow us to look after the finds here and perhaps to get money to look after the forts.

(Quoted from a Class 2 student at Attar al-Maula Boys' Secondary School) 


\section{Teachers}

Among the teachers from both primary and secondary schools, there was consensus that the book would be a significant teaching aid because it was both 'very beautiful and easy to read' (quoted from a teacher at al-Haibel Boys' Primary School in Maqall). Respondents stated it would be particularly helpful for teaching History, Geography, and English. Currently, the curriculum contains nothing specific to local history, meaning that any teaching content about Mograt comes from individual teachers' knowledge. One teacher stated:

We need more and better information to teach History and also to explain to the children what archaeology is. We don't really teach about the history of Mograt other than in recent times as we did not have the information until now. Now we have this information we will be sure to use it!

(Quoted from a teacher at al-Barab Mixed Primary School)

\section{Another respondent added:}

The timeline will be useful for teaching as at the moment teaching History is so hard. It is difficult for the children to understand all the different times.

(Quoted from a teacher at al-Barab Mixed Primary School)

Similarly, in terms of Geography, numerous teachers stressed the difficulty of helping pupils understand their place in the world when Mograt is barely visible on the school atlas. They highlighted the benefit of having the map mention almost every village - no matter how small noting how this would build knowledge about the island as well as pride and a sense of place for both children and adults. Regarding English (and Arabic) teaching, teachers often mentioned the word swap boxes as useful for expanding vocabulary, while also noting that the wider text provided new reading material. As one teacher said,

Everything is here - all our questions are answered in this book.

(Quoted from a teacher at Jerif al- Dauma Mixed Primary School)

The high quality of the publication, with colour and multiple images was frequently cited as adding personal and intellectual value, as there are no books like this available in schools. One teacher stated, 'it is beautiful and interesting' (quoted from a teacher at Salah al-Din Karrar Girls' Secondary School) - implying that it is rare for something to be both of those things.

Many teachers were proud to see the quotations from the children alongside their images in the book.

It is important to show how the children are part of the history and tradition of Mograt.

(Quoted from a teacher at Salah al-Din Karrar Girls' Secondary School)

Teachers felt that these quotations demonstrated that the book 'belongs to us', 'reflects our island and our community' and 'was made by our children' (simplified quotations expressing the 
views of multiple teachers). To us, these aspects conveyed a sense of ownership and partnership with the archaeological team, building on feelings of pride in the island's history and its living community.

A number of the teachers pointed out the importance of the recommendations for helping protect archaeological sites. The headmistress of one school saw another benefit:

The book is good as these days everyone talks about what tribe they are from, Manasir or Rubatab and so on, but the history and stories in the book show that we used to be one people in the past. Now we are separated but this history can be used to bring the people back together again and to make sure we do not say I am from this or that tribe but instead say we are one people.

There was a strong consensus that more such publications were needed to tell the wider story of Sudan's history both to the people of Sudan and the wider world. This was emphasized on several occasions in regard to rivalries with Egypt:

This book and the fact you wrote about us proves that Mograt Island is important.

(Quoted from a teacher at al-Haibel Boys' Primary School in Maqall)

We must show this [the book] to the people of Egypt - it will make them jealous!

(Quotation from a teacher at Kalasaikal Gubli Mixed Primary School)

Sentiments like these highlight that different dynamics can spring from collaborative projects. In our case, association with the heritage as presented and discussed in the book was strong, but interpreted in different directions. One respondent felt it addressed a sense of belonging 'together' among fellow Sudanese, while it bolstered nationalist pride vis-à-vis the neighbouring Egyptians in others. The question of how archaeologists should deal with unwelcome interpretations has not received systematic attention in analyses of community engagement so far. We have identified it as something important to follow up and reflect on in future projects.

\section{The Wider Community}

The book was also in great demand from the Mograt community, once word spread from the pupils and the teachers. Many people read aloud the dedication on the front page and expressed pleasure at being actively acknowledged in the book:

To the people of Mograt who welcomed us to their island, homes and heritage sites.

$$
\text { لسكّان مقرات الذين رحّبوا بنا في جزيرتهم ومنازلهم ومواقعهم التراثية. }
$$

This supported both the sense of collaboration and a feeling of ownership of the heritage discussed in the book.

The map gave rise to the most intense debates among the men, particularly in relation to the section in the book discussing the name of Mograt and the potential connection with Old Nubian 
'sleeping dog' (Tully and Näser 2016, 15, 38). This led to much talk about the origins of other place names on the island and revealed a sense of pride in the continuing Nubian element of Mograt's history. For many, the map also acted as 'proof' of the large size of the island, suggesting that outsiders would now realize this, which in turn would raise Mograt's standing in wider Sudan and beyond. Learning that the Mograt book is the first of its kind in Sudan inspired even greater pride and led many to suggest that we need to make books like this for all the important places within Sudan.

Very few people were aware of, or had visited any of, the archaeological sites mentioned in the book. After reading the book, many respondents expressed an interest in seeing the sites and learning more about them. One young woman who now lives in Khartoum and had returned to visit family had a clear interest in history. She had been to the National Museum and other museums in Khartoum and to the pyramids at Meroe. She said she had visited the forts at Maqall, Sangairab and Ras al-Jazira, but 'until seeing the book had not realized the island had so much history.'

The photographs of the skeletons from the multi-period cemetery MOG034 led many to talk about human bones or other objects they had discovered around the island, often when building houses. This prompted people to share their knowledge and express the desire to learn more about what they had found. A group of teenage boys at Maqall stated how important it is that the book shows ancient and modern life, and that if more books like this are created they should show 'the continuation of people from the old times until now and discuss similarities and differences.' One boy gave the example of Maqall fortress saying that it had many uses including a baniya, i.e. holy place (Näser forthcoming), and before that, a hide out during the Mahdiya. This reflects how the book started discussions not only between community members and archaeologists, but within the community itself. In the case of Maqall, repeated disagreements on which stories were correct led people to say things as, 'you have to continue working here and find the answers'.

In terms of perceptions of archaeology, before engaging with the project most people only knew that archaeologists were interested in 'old things' and 'dug holes' to find them. The notion that archaeologists only look for gold was pervasive. The book led many to comment on this not being the case, and to express a new appreciation for the complexity of archaeology and the 'science' behind it. A comment by one of the excavation workmen highlighted this issue and the potential of our work to address it:

The book and working with archaeologists changed my opinion, as before I thought foreigners came and took gold from the graves, but now I know that things are different, and there is no gold and I tell people this.

\section{The Archaeological Team}

Among the team members, the production of the book and its reception triggered reflection on how meaning about archaeological work is created by members of the local community, and the impact that the presence, or absence, of collaboration has on this. Both those team members who participated in the project and those who were not actively involved reported what they learnt from it. Following are our reflections.

Claudia Näser:

The biggest lesson I drew from it was how producing the book was much more labour-intensive than writing a 'straightforward' academic publication. I had not expected that the dialogical setting would require more resources than my usual 
mode of speaking with the monological authoritarian voice of the specialist. But I also gained a taste for it. I enjoyed exploring a new territory in the 'border world' (Haig-Brown in Haig-Brown and Archibald 1996, 250) between academia and the public, and between me as a foreigner and the Sudanese who are our hosts and partners in this work. Looking at how much I have learnt and continue to learn (e.g. by co-authoring this paper) also made me realize that none of this has been a topic in my academic training and the field of Sudanese archaeology in which I have worked for more than two decades. I understood that part of doing collaborative archaeology is also seeking communication with members of my academic community about this approach and why we should adopt it. Among other things, this paper is to serve this purpose.

\section{Gemma Tully:}

The entire process of co-creating and disseminating the book was an extremely rewarding experience. I have been involved in collaborative archaeology projects for over 15 years and have often felt disappointed that the outputs are dictated by funding applications (as opposed to stakeholders). As a result of these limitations, the impact of the work is diminished and projects are quickly forgotten as the needs of different stakeholders are rarely met. On Mograt, the lack of expectation (from us, the funders, and local communities) freed up the entire process. This allowed us, namely the archaeological team and interested community members, to build something original, which sparked interest on multiple levels, was needed, and would be valued by all those involved. This is how many (e.g. Moser et al. 2002; Thomas 2017) have argued that this form of community archaeology should be done in postcolonial and other contexts. In reality, academic processes mean that such outcomes can be hard to achieve. Thus, the Mograt experience is an important case study and needs to be followed up in the coming years to see whether the apparent impacts are sustained and perceptible in the longer-term.

\section{Discussion and Outlook}

Collaborative archaeology is a balancing act, as is self-evaluation. Giblin $(2017,428)$ maintains that presentations of one's own projects in a case study framework:

....are important because experiences need to be shared and critically reflected upon. However, they also have inherent and unavoidable flaws because they are written by the practitioner(s) at the centre of the story and so risk being self-congratulatory and sermonic at one extreme or becoming a form of self-flagellation at the other.

We have reported that the work of the Mograt Island Collaborative Project was appreciated by those who participated in it and by those who received the resulting publication. The vast majority of those involved expressed a keen interest in learning more about our archaeological narratives and having accessible resources in Arabic on that topic. We consider this a significant result that contributes to the wider debate about collaborative archaeology in Sudan and other majority Muslim contexts in Southwest Asia and North Africa. 
We did not receive any negative feedback, but in hindsight, we need to acknowledge that we did not ask directly what people did not like about the book. Even so, all feedback emerged in open communicative situations - so there were opportunities to raise problems or make negative comments. However, in the wave of positivity around the project, it is possible that those who were critical did not come forward. Future evaluation may reveal these elements more clearly.

The book and the process of its production, which led from the questions and perspectives of local residents, rather than from our expectations and an abstract idea of what members of the community should 'learn' about 'their' heritage, were effective in starting discussions, and sharing knowledge and perspectives about the past. Thus, the key aim of the project was fulfilled. What impact the Mograt publication will have over time remains to be seen and, despite considerable enthusiasm from all sides, should not be overestimated.

Currently, it has acted as a springboard for further projects on the island and beyond. We have just had another 5000 copies of the book printed in Khartoum in order to be able to give each student on Mograt a copy and have enough stock for wider circulation, and are currently producing further resources for local schools such as large maps and posters on different topics based on the book's content. The Arabic version of our project website recently went live (https://www.mogratarchaeology.com). The content of the website takes up discussions from the collaborative project as well. We created it with four aims in mind. First, it provides easily accessible and contextualised information on the history of the island and Sudan in general. Second, we use it to introduce us as members of the archaeological team and as individuals, and explain our motivations for coming to Mograt. Third, the section 'How we work' answers questions which we are frequently asked by members of the local community. Finally, the site satisfies the request of many project participants on Mograt to share our work not only with them, but also with other publics in Sudan and the wider world.

As noted, one aspect which kept coming up throughout the project was the creation of a museum, despite many community members never having visited one. In the dynamic that unfolded around our work, the commissioner of Abu Hamed, the local district capital on the main river bank opposite Mograt (fig. 1), visited the archaeological team on the island and subsequently offered a colonial period building in Abu Hamed as a museum space. In the beginning, it seemed ironic and made us uneasy that a project which challenges repercussions of the colonial past, i.e. practices of exclusion and separation of local stakeholders from cultural resources, resulted in the invitation to (re)inhabit a colonial space. However, research with other Sudanese publics and collaboration with Sudanese colleagues has shown how multi-layered and ambivalent the attitudes of Sudanese are to their colonial history (more on this in Näser forthcoming). The commissioner's offer clearly expressed appreciation for the project.

In the meantime, we started research into the history of the building in question. It is shown in a photograph taken by a colonial officer in about 1932, which today is kept in the Sudan Archive Durham (SAD.747.2.31). The caption of the image identifies it as the markaz, the main office building used by colonial administrators on their visits to Abu Hamed. We have since corroborated this information with a local historian at Abu Hamed. Until offered to us, the building housed offices of the district administration. So, why did the commissioner offer it to us? We put this question to the Sudanese colleague who had followed up on the procedural side of things. He explained that, while nobody knew how old the building was, it must be nearly 100 years old, and has thus approached monument status. Because of this, the commissioner thought it would make an appropriate space for a museum. Moreover, it is in a bad state of repair and the local administration does not command 
the resources necessary for its rehabilitation. Giving it to us solved this problem - the involved administrators saw it as the best chance to achieve the building's survival. It is now vacated, and we conducted an architectural condition survey in spring 2019.

But why would the commissioner want it to be rehabilitated, i.e. how does its colonial history resonate in the present? Throughout this paper we have touched lightly upon the issue of colonialism - we let community members guide us in identifying topics of engagement. Their interests evolved around our presence and our activities on the island, places which residents learnt to appreciate as archaeological sites through our discussions and aspects of the past which can be approached through them. The colonial era, as well as other periods of potentially difficult and painful history, such as the Turkiya and the Mahdiya, figured only marginally in these discussions, even though we included them in our timeline (fig. 3). Establishing a museum in Abu Hamed will bring these issues to the fore, and one of the things we will have to learn from local community members is how extant colonial era monuments actually figure in their collective and individual constructions of the past (see Weschenfelder and Becker 2018).

How our work on Mograt and in Abu Hamed will develop, and whether we can see the museum project through to completion, will depend on many factors. One crucial aspect will be our ability to continue investing our time and find funding. This will entail lobbying for the project in academic and funding circles as well as fitting it into the framework of academic relevance and output. In this respect, the first phase of the project, reported here, benefitted from a highly unusual funding situation which left us free to pursue an open project design. We were not restrained by having to anticipate project content and output in an application and work towards its fulfilment later. Instead, we were able to define content and output together with local partners during the course of the project. This unusual context also allowed us to work towards an outcome which most funding bodies might not have considered sufficient given typical requirements to demonstrate 'major impact'. Our case study shows that a collaborative process takes considerable resources of both funding and time. Against this background, we argue that it is important to form and communicate a realistic outlook of the potential outcomes and impacts that this kind of engagement can achieve (see De Leiuen and Arthure 2016, 94-95). The vicious circle of exaggerated demands from funding bodies and unrealistic claims of impact from applicants may be an additional hindrance for the wider use of collaborative approaches in our study region and beyond. We suggest that integrating short-, medium- and long-term evaluations in project designs may provide greater transparency on this point, and see our paper as a step towards this goal.

In view of these challenges and uncertainties, we must be open and specific about the risks of our efforts, as well as their potential benefits, sustainability, and impact. With the first phase of the Mograt project, we aimed for a modest output which maximized the chances of its completion. Even so, a temporary halt in funding put the collaborative process at risk. While we can expect these contingencies along the way, it is still difficult to mitigate them when they do occur. The proposed Abu Hamed Museum project is, however, much more substantial, and given the political and economic contexts in which we are working, on top of the challenges we just discussed, it has a larger risk of failing. ${ }^{7}$ We entitled our paper 'Dialogues in the Making' because we do not consider the completed museum itself as the next 'outcome' of our project. Rather, our next outcomes will be what we learn about whether (and how) to collaboratively develop and implement such a space. It is not only the result, but also the process of working towards it which will open new spaces for engagement between us as archaeologists and our host communities. The process will itself add new perspectives to the existing resources upon which Sudanese publics can draw when constructing their past and sharing it with other stakeholders. 


\section{Acknowledgements}

We thank all partners in the Mograt Collaborative Project, both residents of Mograt and the members of the archaeological mission, and other stakeholders. Special thanks go to Hassan Mustafa Alkhidir, Rehab Ismail Alfaki and Gareth Rees who were part of the project's fieldwork team in 2015 and 2018. We are grateful to Salah Mohamed Ahmed, General Coordinator of the Qatar-Sudan Archaeological Project, Abdelrahman Ali Mohamed, Director General of the National Corporation for Antiquities and Museums, and Amel Hassan Gismallah, Co-Director of the Mograt Island Archaeological Mission, for their continued support.

\section{Funding details}

This work was supported by the Qatar-Sudan Archaeological Project, registered as non-governmental organization under the name Nubian Archaeological Development Organisation in Sudan (http://www.qsap.org.qa/en/about-us.html).

\section{Disclosure statement}

No potential conflict of interest was reported by the authors.

\section{References}

Abdel-Qadr, Mustafa, Willeke Z. Wendrich, Zbigniew Kosc, and Hans Barnard. 2013. 'Giving a Voice to the Ababda.' In The History of the Peoples of the Eastern Desert, edited by Hans Barnard and Kim Duistermaat, 399-414. Los Angeles: University of California Press.

Ahmed, Abbas Sid. 1971. 'The Antiquities of Mograt Island.' Sudan Notes and Records 52, 1-22.

Atalay, Sonya. 2006. 'Indigenous Archaeology as Decolonizing Practice.' The American Indian Quarterly 30(3): 280-310.

Bos-Seldenthuis, Jolanda E.M.F. 2007. 'Life and Tradition of the Ababda Nomads in the Egyptian Desert, the Junction Between Intangible and Tangible Heritage Management.' International Journal of Intangible Heritage 2: 31-43.

Castañeda, Quetzil E., and Christopher N. Matthews, eds. 2008. Ethnographic Archaeologies: Reflection on Stakeholders and Archaeological Practices. Plymouth: Altamira.

Carruthers, William. 2016. "Multilateral Possibilities: Decolonization, Preservation, and the Case of Egypt." Future Anterior 12: 36-48.

Chevrillon-Guibert, Raphaëlle 2018. 'Le gouvernement des mines au Soudan: entre opportunisme et autoritarisme', Égypte/Monde arabe, Troisième série 18. URL: http://journals.openedition.org/ema/4176 ; DOI : 10.4000/ema.4176.

Colla, Elliott. 2007. Conflicted Antiquities: Egyptology, Egyptomania, Egyptian Modernity. Durham, NC: Duke University Press. 
De Leiuen, Cherrie, and Susan Arthure. 2016. 'Collaboration on Whose Terms? Using the IAP2 Community Engagement Model for Archaeology in Kapunda, South Australia', Journal of Community Archaeology \& Heritage 3(2): 81-98.

Fushiya, Tomomi 2010. 'Archaeological Site Management and Local Involvement: A Case Study from Abu Rawash, Egypt.' Conservation and Management of Archaeological Sites 12 (4): 324-355.

Fushiya, Tomomi. 2017. 'Connecting Archaeology and Local Communities at Amara West.' The British Museum Newsletter Egypt and Sudan 4: 33.

الحياة في قلب النوبة: . Fushiya, Tomomi, Shireen Ahmed, Fekri Hassan Taha, and Hassan Sorta, eds. 2017 [Life in the Heart of Nubia: Abri, Amara East and Ernetta Island]. Khartoum: The British Museum Amara West Research Project.

Giblin, John. 2017. 'Book Review: Community Archaeology and Heritage in Africa: Decolonizing Practice, Edited by Peter R. Schmidt and Innocent Pikirayi.' Azania: Archaeological Research in Africa 52 (3): 428-429.

Haberlah, David. 2007. 'Cultural Landscape of Dar al-Manasir.' In Proceedings of the Second International Conference on the Archaeology of the Fourth Nile Cataract. Berlin, August $4^{\text {th }}-6^{\text {th }}, 2005$, Meroitica 23, edited by Claudia Näser and Mathias Lange, 159-178. Wiesbaden: Harrassowitz.

Haig-Brown, Celia, and Jo-ann Archibald. 1996. 'Transforming First Nations Research with Respect and Power.' International Journal of Qualitative Studies in Education 9 (3): 245-267.

Hamilakis, Yannis. 2011. 'Archaeological Ethnography: A Multi-Temporal Meeting Ground for Archaeology and Anthropology.' Annual Review of Anthropology 40: 399-414.

Hanna, Monica, Fatma Keshk, and Sara Aboubakr. 2013. 'The Documentation of the Cultural Heritage of the Bedouin of South Sinai: A Pilot Study in Serabit al-Khadim.' In The History of the Peoples of the Eastern Desert, edited by Hans Barnard and Kim Duistermaat, 358-368. Los Angeles: University of California Press.

Humphris, Jane, and Rebecca Bradshaw. 2017. 'Understanding 'the Community' Before Community Archaeology: A Case Study From Sudan.' Journal of Community Archaeology \& Heritage 4 (3): 203217.

La Salle, Marina J. 2010. 'Community Collaboration and Other Good Intentions.' Archaeologies 6 (3): 401-422.

Lorenzon, Marta, and Isabel Zermani. 2016. 'Common Ground: Community Archaeology in Egypt, Interaction Between Population and Cultural Heritage.' Journal of Community Archaeology \& Heritage 3 (3): 183-199.

McDavid, Carol 2007. 'Beyond Strategy and Good Intentions: Archaeology, Race and White Privilege.' In Archaeology as a Tool of Civic Engagement, edited by Barbara J. Little and Paul A. Shackel, 67-88, Lanham: Altamira Press.

Mehari, Asmeret G., and Kokeli P. Ryano. 2016. 'Maasai People and Oldupai (Olduvai) Gorge: Looking for Sustainable People-Centered Approaches and Practices.' In Community Archaeology and Heritage in Africa: Decolonizing Practice, edited by Peter R. Schmidt and Innocent Pikirayi, 21-45. Milton Park: Routledge.

Moser Stephanie, Darren Glazier, James E. Phillips, Lamya Nasser el Nemr, Mohammed Saleh Mousa, Rascha Nasr Aiesh, Susan Richardson, Andrew Conner, and Michael Seymour. 2002. 'Transforming 
Archaeology Through Practice: Strategies for Collaborative Archaeology and the Community Archaeology Project at Quseir, Egypt.' World Archaeology 34 (2): 220-248.

Moshenska, Gabriel. 2017. 'Introduction: Public Archaeology as Practice and Scholarship where Archaeology Meets the World.' In Key Concepts in Public Archaeology, edited by Gabriel Moshenska, 1-13. London: UCL Press.

Murray, Tim. 2011. 'Archaeologists and Indigenous People: A Maturing Relationship?' Annual Review of Anthropology 40: 363-378.

Näser, Claudia. 2007. 'The Humboldt University Nubian Expedition 2005: Survey and Excavations on the Islands Sherari and Us.' In Proceedings of the Second International Conference on the Archaeology of the Fourth Nile Cataract. Berlin, August $4^{\text {th }}-6^{\text {th }}, 2005$, Meroitica 23, edited by Claudia Näser and Mathias Lange, 118-133. Wiesbaden: Harrassowitz.

Näser, Claudia. Forthcoming. 'Majority Muslim Communities, Archaeology and the pre-Islamic Past: Two Case Studies from the Nile valley.' Journal of Social Archaeology.

Näser, Claudia, and Cornelia Kleinitz. 2012. 'The Good, the Bad and the Ugly: A Case Study on the Politicisation of Archaeology and Its Consequences from Northern Sudan.' In "Nihna nâs al-bahar We are the people of the river." Ethnographic Research in the Fourth Nile Cataract Region, Sudan. Meroitica 26, edited by Cornelia Kleinitz and Claudia Näser, 269-304. Wiesbaden: Harrassowitz.

Petersen, Andrew. 2013. The Archaeology of Death and Burial in the Islamic World. In: The Oxford Handbook of the Archaeology of Death and Burial edited by Sarah Tarlow and Liv Nilsson Stutz, 241258. Oxford: Oxford University Press.

Pyburn, K. Anne. 2007. Archaeology as Activism. In Cultural Heritage and Human Rights, edited by Helaine Silverman and D. Fairchild Ruggles, 172-183. New York: Springer.

Regulski, Ilona. 2018. 'Sustainable Cultural Heritage Preservation in Middle Egypt.' Egyptian Archaeology 52: 20-25.

Ritter, Mathias. 2014. 'A New Topographic Map of Mograt Island.' Der Antike Sudan. Mitteilungen der Sudanarchäologischen Gesellschaft zu Berlin 25: 123-125.

Ryan, Philippa. 2018. الزراعة والمحاصيل والطعام في النوبة. الماضي والحاضر [Nubia Past and Present. Agriculture Crops and Food]. London: The British Museum.

Scham, Sandra A. 2003. "Ancient Egypt and the Archaeology of the Disenfranchised." In Views of Ancient Egypt since Napoleon Bonaparte: Imperialism, Colonialism and Modern Appropriations, edited by David Jeffreys, 171-178. London: UCL Press.

Smith, Claire, and H. Martin Wobst (eds). 2005. Indigenous Archaeologies. Decolonizing Theory and Practice. One World Archaeology 47. Milton Park: Routledge.

Thomas, Suzie. 2017. 'Community Archaeology.' In Key Concepts in Public Archaeology, edited by Gabriel Moshenska, 14-30. London: UCL Press.

Trigger, Bruce G. 1984. "Alternative Archaeologies: Nationalist, Colonialist, Imperialist." Man, New Series 19 (3): 355-370.

Trigger, Bruce G. 1994. "Paradigms in Sudan Archaeology." International Journal of African Historical Studies 27: 323-345. 
Tully, Gemma. 2009. 'Ten Years On: The Community Archaeology Project Quseir, Egypt.' Treballs d'Arqueologia 15: 63-78.

Tully, Gemma. 2014. 'Community Archaeology on Mograt Island: Sharing Spaces, Understanding Sites.' Der antike Sudan. Mitteilungen der Sudanarchäologischen Gesellschaft zu Berlin 25: 155-160.

Tully, Gemma. 2015. 'Community Archaeology in Sudan: Discovering Mograt Island Together.' Der Antike Sudan. Mitteilungen der Sudanarchäologischen Gesellschaft zu Berlin 26: 201-204.

Tully, Gemma, and Michael J. Allen. 2018. 'Participatory Augering: A Methodology for Challenging Perceptions of Archaeology and Landscape Change.' Public Archaeology: Public Archaeology 16: 191213. doi:10.1080/14655187.2018.1496519.

Tully, Gemma, and Monica Hanna. 2013. 'One Landscape, Many Tenants: Uncovering Multiple Claims, Visions and Meanings on the Theban Necropolis.' Archaeologies 9 (3): 362-397.

نuتكشق معاً جزيرة مقرات - Tully, Gemma, and Claudia Näser. 2016. Discovering Mograt Island Together هي/ London: Golden House.

Wendrich. Willeke 2008. 'From Objects to Agents: The Ababda Nomads and the Interpretation of the Past.' In The Archaeology of Mobility: Old World and New World Nomadism, edited by Hans Barnard and Willeke Wendrich, 509-542. Los Angeles: Cotsen Institute of Archaeology.

Weschenfelder, Petra, and Peter Becker. 2018. 'The Fortress of Maqall - Community Archaeology and Cultural Heritage on Mograt Island, Sudan.' Der Antike Sudan. Mitteilungen der Sudanarchäologischen Gesellschaft zu Berlin 29: 71-87.

Zimmerman, Larry Z. 2008. 'Real People or Reconstructed People? Ethnocritical Archaeology, Ethnography, and Community Building.' In Ethnographic Archaeologies: Reflection on Stakeholders and Archaeological Practices, edited by Quetzil Castañeda and Christopher N. Matthews, 183-204. Plymouth: Altamira.

\section{Notes on contributors}

Claudia Näser joined University College London as a Lecturer in Egyptian Archaeology in 2017 after having taught Northeast African Archaeology as Junior and Guest Professor at Humboldt University Berlin. She holds a PhD in Egyptology from Humboldt University and an MPhil in World Archaeology, option African Archaeology, from the University of Cambridge. Claudia has worked in Sudan for more than two decades and has been directing major archaeological salvage and research projects since 2004. She is particularly interested in the present-day political and social dimensions of archaeology and in approaches to decolonizing disciplinary practices.

Gemma Tully is a community archaeologist and museum professional who has worked on collaborative archaeology and museum outreach projects in Egypt, Sudan and Europe for over 15 years. After obtaining her PhD in Archaeology from Southampton University, she worked in museum learning for five years before taking up post-doctoral positions first at Durham University and then the University of Cambridge, where she is currently based. Gemma has also taught archaeology and museum studies courses at MA and Undergraduate level at Durham University and Humboldt University in Berlin. She is interested in developing new approaches to stakeholder collaboration which incorporate the landscape-scale of heritage and is an avid promoter of the use of contemporary art in non-art museums. 


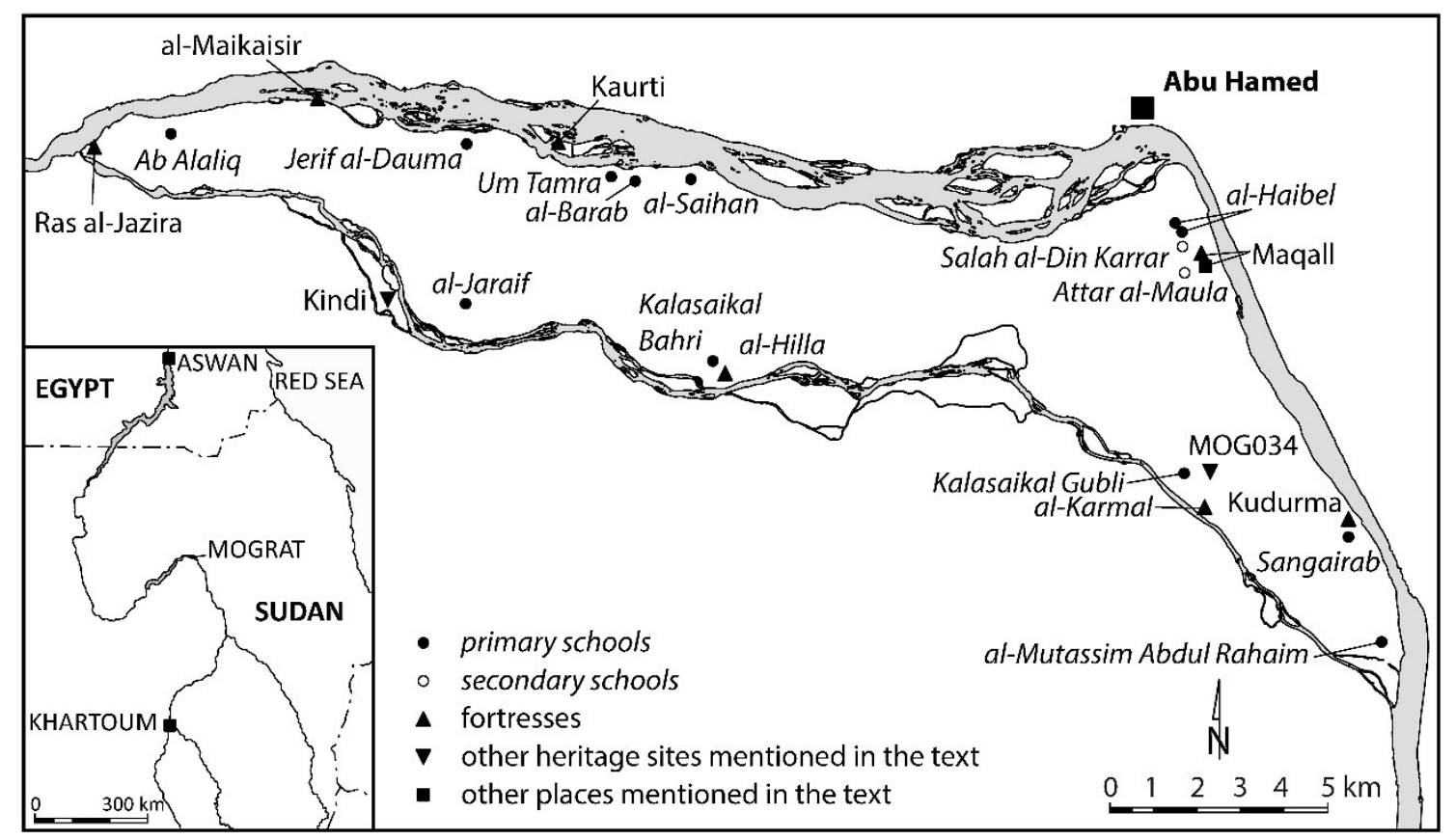

Fig. 1 Map of Mograt island indicating locales of schools and the sites mentioned in the paper (image: Kay Kossatz, based on Ritter 2014)

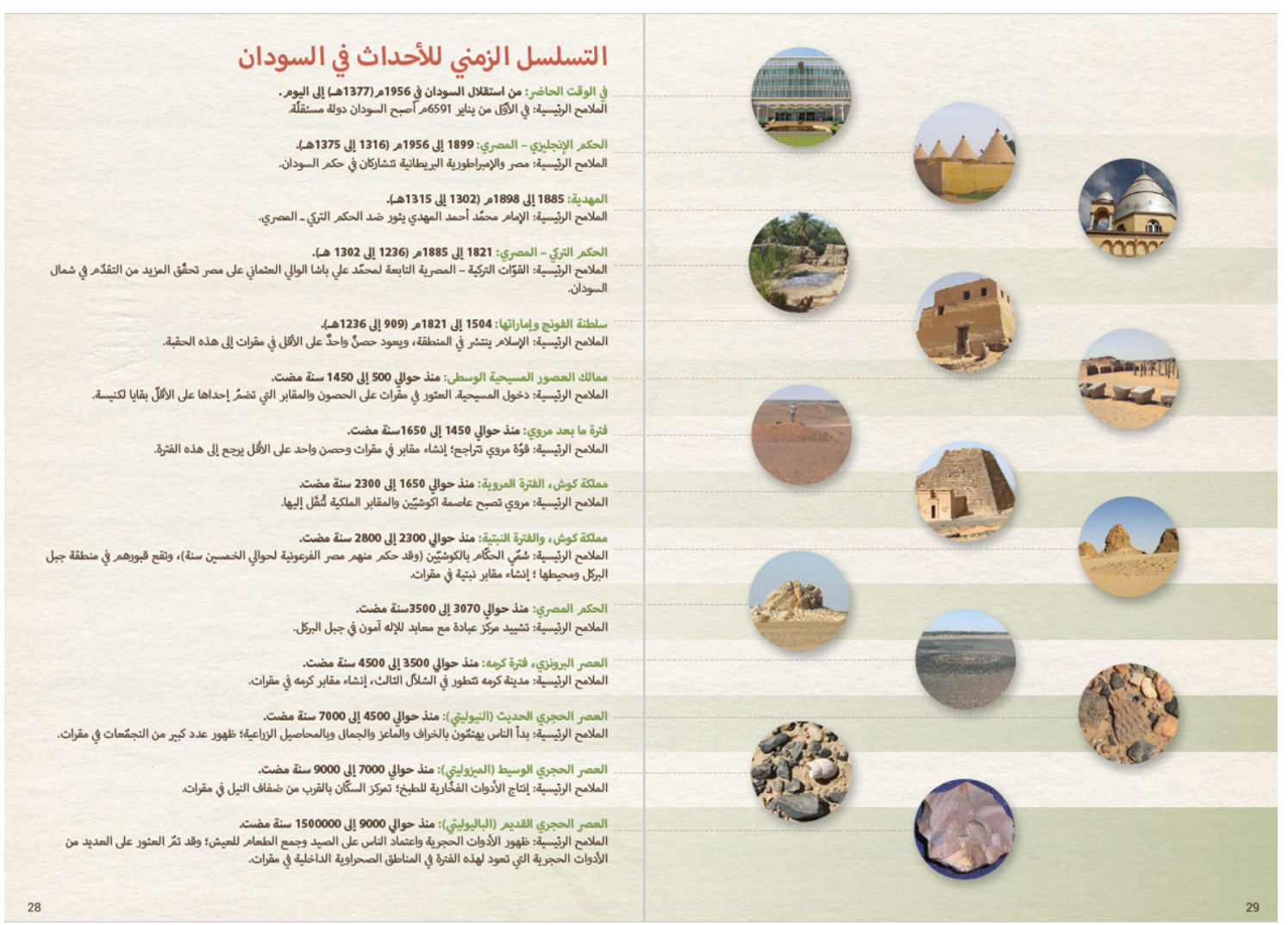

Fig. 2 Timeline from 'Discovering Mograt Island Together' (Tully and Näser 2016, 28-29) 


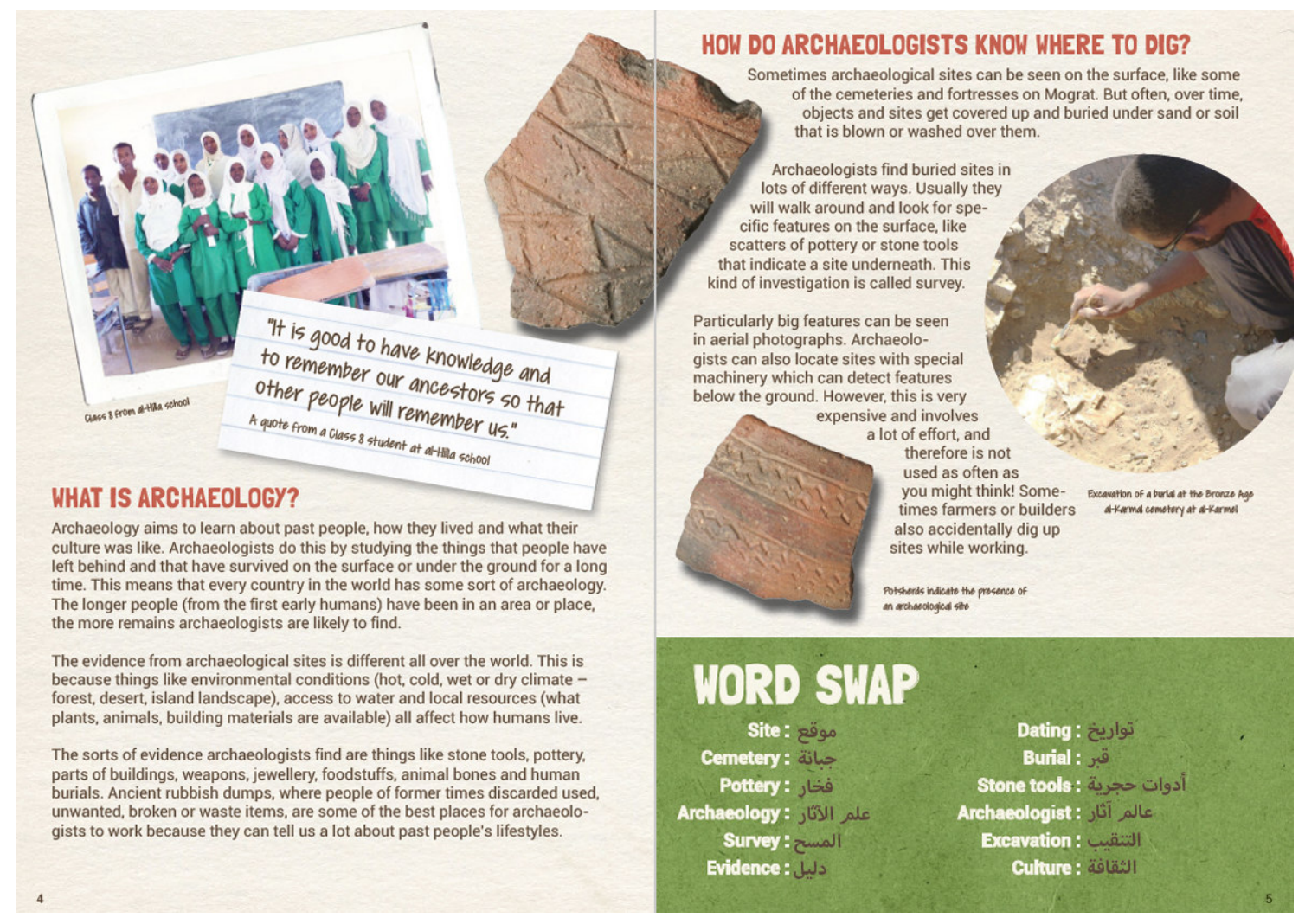

Fig. 3 A page from the Mograt book including a word swap box, quotation and photograph of children who helped develop the book (Tully and Näser 2016, 4-5)

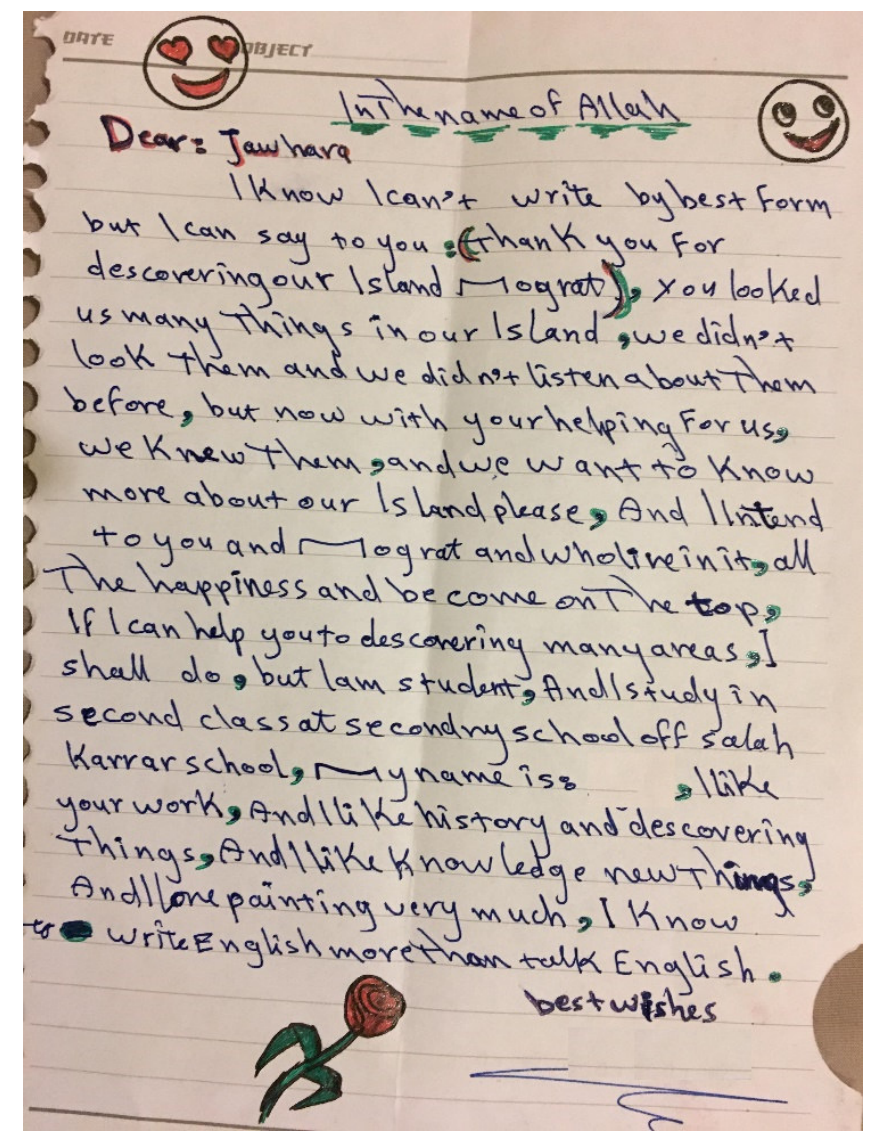

Fig. 4 Letter to Gemma Tully from a Class 2 student at Salah al-Din Karrar Girls' Secondary School (author anonymized in compliance with IOA UCL ethical guidelines for human participant research) 
Additional images for this paper, on top of those reproduced in the print version, are available online at [Online Images and Captions.pdf]. The publication Tully and Näser (2016) as well as the associated map can be downloaded from [Tully_Näser_2016_Mograt_Book] and [Tully_Näser_2016_Mograt_Map].

${ }^{1}$ Figures were estimated from current lists of archaeological fieldwork projects in Egypt in the journal Archaeology https://www.academia.edu/38218789/Updated list of current working missions in Egypt and S udan.pdf.

${ }^{2}$ In the context of Nile valley archaeology, 'mission' refers to an organizational unit working at a given archaeological site or region. In contrast to more short-termed 'projects', the use of the term 'mission' implies a commitment over an extended period of time. Critical reflection about the obviously colonial origins of the term (referencing a body of persons sent to a foreign country to undertake a specific task) is beyond our scope here.

${ }^{3} \mathrm{https}$ ://britishmuseumamarawestblog.wordpress.com/category/community-engagement/.

${ }^{4}$ The project was based at Humboldt University Berlin from 2013 to 2015, and continued under the auspices of an NGO under German law since 2016. Neither of these bodies requires or grants ethics approval in a formal procedure. Therefore, we voluntarily conducted the project following the Code of Ethics of the Deutsche Gesellschaft für Sozial- und Kulturanthropologie (German Anthropological Association: https://en.dgska.de/ethics/) and the Code of Ethics of the Society of Africanist Archaeologists (http://safa.rice.edu/SAfA Info/SAfA Code of Ethics/, amended in 2016). Publishing as members of University College London and the University of Cambridge, we also follow ethical guidelines for human participant research of these institutions with regard to the anonymization of project participants in this paper.

${ }^{5}$ Late antique, Medieval and Islamic fortifications formed another main group of sites investigated by the Mograt Island Archaeological Mission.

${ }^{6}$ In Sudan, there are no issues with excavating human remains, unless a grave is identified as Muslim, in which case archaeologists will not touch it (see Petersen 2013, 253-255 for a wider survey of attitudes towards the archaeological excavation of Muslim burials). In our discussions on Mograt, skeletal remains and what archaeologists learn from them were a main attraction for both schoolaged children and adults, and local residents loved to visit the excavation of the multi-period burial ground MOG034 in al-Karmal.

${ }^{7}$ We revised this paper in April 2019, as mass protests in Sudan led to the overthrow of Omar alBashir and his regime. Together with our Sudanese colleagues Amel Hassan Gismallah, Osman Khaleel Elawad Karrar and Mohamed Mohamed el-Tayeb Badri we try to maintain project momentum, despite future uncertainties. 